Conference Paper

\title{
Analysis of Debt Restructuring Methods for Negative Equity Firm
}

\author{
Ikhsan Abi Nubli, Viverita* \\ Department of Management, Faculty of Economics and Business, Universitas Indonesia
}

*Corresponding author:

E-mail: viverita.d@ui.ac.id

\begin{abstract}
This paper aims to find the best debt restructuring methods for negative equity firms. This study uses four common debt restructuring methods, i.e. Debt-to-Equity swaps, debt-to-asset swaps, issuing convertible bonds, and repayment agreements. Furthermore, based on each debt structure, we compared their price-to-book ratio and debt-toequity ratio (DER) to find the best possible method for every firm and their industries. The sample for this study is firms listed on the Indonesia Stock Exchange (IDX). The ideal capital structure of the firms is determined by using an iterative algorithm. After finding their ideal capital structure, firms will be treated by debt restructuring to reach their ideal capital structure. Mostly, firms are better performances while using debt to an equity swap and issuing convertible bonds. This condition is proven by increasing their P/BV and their better capital structure by looking at their DER. Furthermore, debt to asset swap is better to use for firms with high DER. Whilst debt repayment agreements do not affect the firm's capital structure and its value.
\end{abstract}

Keywords: Debt restructuring, capital structure, negative shareholders equity, simulations, iterative algorithms, firms, industries

\section{Introduction}

The book value of the firm represented the difference between the firm's asset and liability and usually measured the amount of shareholder's equity (Bragg, 2017). However, if the value of shareholder's equity is less than zero, it means firms had more liabilities than assets. Financially distressed firms usually experience a negative value of the shareholder's equity and this situation mostly due to a negative accrual net income and resulted in deficit retained earnings (Bragg, 2017). Thus, firms' liquidity problems and profit will affect their leverage and capital structure. Therefore, they need to restructure their financial condition (Harmon, 2020). A negative value of the shareholder's equity also affects the firm's capital structure and the composition of its assets (Masulis \& Korwar, 1986). The firms also have a high default risk they experience negative shareholders' equity and affect their premium value than a usual firm with an ideal capital structure (Brown et al., 2008).

Debt restructuring is not only a signal for financially distressed firms but also a sign for firms to improve their financial health, so it can minimalize their bankruptcy risk. Debt restructuring has also improved the connection between creditors so that firms can expand and having more room to adapt, even though debt restructuring has examined from many aspects such as capital structure, revenue management, and also their restructuring system (Gilson et al., 1990; Saleh \& Ahmed, 2005; Lee, 2007; Pawlina, 2010; Huang \& Huang, 2011; Miyakawa \& Ohashi, 2016; Hoshi et al., 2018; Payne, 2018).

In this study, there are three methods to be used. They are debt-to-equity swap, issuing convertible bonds, debt - to - asset swap, and debt repayment agreements (Choi \& Han, 2013). The effectivity of the debt restructuring method can be measured by the firms' value-added so for measuring the firm's value-added, we use price-to-book value ratio (P/BV) (Hilliard \& Zhang, 2015).

As of December 2019, there are 28 firms with negative equity in the Indonesian stock exchange. From an accounting perspective, those firms are susceptible to bankruptcy, caused by their assets had smaller amounts than their liabilities, so that firms had negative shareholders equity. Therefore, they

How to cite:

Nubli, I. A., \& Viverita. (2021). Analysis of debt restructuring methods for negative equity firm. $1^{\text {st }}$ ICEMAC 2020: International Conference on Economics, Management, and Accounting. NST Proceedings. pages 1-15. doi: 10.11594/ nstp.2021.1001 
need to find the most effective debt restructuring method. Each debt restructuring method had its disadvantages and advantages. One of the advantages of the debt-to-asset swap method is gain of restructuring - firm's expected to gain more from the collateral asset for payment of a debt. According to Eric \& Stosic (2013) Nevertheless, if their collateral assets are less than their debt, firms are expected to find alternative ways to restructure their debt or filing for bankruptcy.

Furthermore, other alternatives are issuing convertible bonds. The issuer does not need to settle their bond value since it will be converted into shares after the due date so that firms needed to issue bond value as much as the number of shares needed. However, it will affect shareholders' ownership because it will be diluted after bondholders already exercised their rights to convert (Viva \& El Hefnawy, 2020). Debt repayment is one of the standard methods of debt restructuring. Firms have an agreement to delay the payment to the creditors, based on the law for debt restructuring purposes (Fuady, 2001).

The purpose of this study is to find the most effective debt restructuring methods for 28 publicly traded firms with negative shareholder equity. Data will be used in this study to be withdrawn from the firm's financial statement, and the debt restructuring method mentioned above will be used as a treatment for data.

This article is organized as follows. Section 2 provides a brief review of the related literature. Section 3 introduces both the data and the methodology used in the study. Section 4 presents the findings and draws the main implications, while Section 5 presents the conclusion of the study.

\section{Literature Review \\ Capital structure}

A firm's capital structure is a combination of non - current liabilities and a firm's equity to run its operations (Ross et al., 2010). The composition of a firm's capital structure will affect the risks of the firms and their valuation (Ross et al., 2010). The capital structure is shown portions of a firm's stakeholders which affected the firms in shareholder's equity and the firm's liabilities (Ross et al., 2010). The relationship between capital structure between profitability and theory, which explained by Modigliani and Miller (1963) mentioned that firms would issue debt to gain tax shields. Usually, firms will prefer issuing debt to equity to fund a project (Myers, 1984). This happened because issuing debt will cost less than shareholder's equity because of reputations on the debt capital market (La Rocca et al., 2009). One study about capital structure found that issuing non - current liabilities, significantly is not affected towards profitability if it was inspected towards the return of equity (ROE) (Ebid, 2009).

\section{Debt restructuring methods}

Restructuring is a way to solve a firm's capital structure. Restructuring needed to be done because of the risk of insolvency faced by the firm. There are four aspects of the restructuring, i.e. managerial, operational, assets, and financial (Sudarsanam \& Lai, 2001). Organizational restructuring is significant changes in personnel on the firm's strategic position such as the board of directors, commissioners for implementing new strategy and vision towards a new era for the firm (Lohrke et al., 2004). The operational restructuring aims for increasing their profitability by controlling their cost and eliminated costs from fixed assets. Usually, firms tend to sell their fixed assets and generate cash from it.

Nevertheless, selling assets would not impact firms (Sudarsanam \& Lai, 2001). Financial restructuring is usually marked by dividend policy or capital structure. Sometimes, firms needed to change their strategies for their capital structure from liability and equity aspects. On a debt aspect, there is a change in interest rate, maturity debt, and changes in debt to equity ratio to solve their capital structure (Koh et al., 2015). Debt restructuring in emerging markets is mostly focused on recapitalizing assets than financial growth (Kim et al., 2019). Debt restructuring methods are limited to four methods. Those four methods are a debt to equity swap, issuing convertible bonds, debt to an asset swap, and debt repayment agreement.

Firms usually very dependent on the bank to fund their investment. Nonetheless, if firms had trouble paying their debt, they would usually restructure their debt. (Allen \& Gale, 2000). Asset recapitalization is usually considered a solution to solve financial distress (Moreno-Bromberg \&Vo, 2017). Generally, firms finance their investment by using debt securities and rarely adding more share capital (Högfeldt \& Oborenko, 2005). As a result, financially distressed firms tend to swap their debt to become equity. 
Debt to equity swap is one way to recover from financial distress or insolvency. This method works by writing off a large portion of the debt and swap it to become equity (Gilson et al., 1990). Debt to equity swap allows firms to choose options to solve their insolvency. In implementing debt to equity swap, the firm changes and swaps the debt into shares to their creditors. So, creditors now owned a part of the firms. On the other hand, convertible bonds are hybrid bonds, which means the bonds had equity and also debt characteristics. This particular bond had interest obligatory to be paid by its issuer, and its holders have a right to convert their bonds into shares. Generally, the advantages of issuing convertible bonds are from asymmetric information, agency problem, and taxes (Viva \& El Hefnawy, 2020). Debt repayment agreement is one of the debt restructuring methods used primarily by financial distressed and cash-strapped firms to pay their current liabilities or pay their expiring debt. Repayment agreements are generally used if firms are in the restructuring process (Fuady, 2010). The firm's value would usually be decreased if they decided to use repayment agreement methods (Charalambides \& Koussis, 2017). Other methods are debt to asset swaps. Debt to asset swap is an alternative method for cash-strapped firms. This method uses transactions from selling the firm's assets to writing off portions of the firm's debt. Asset swap is also one of strategy to facilitate select purpose vehicles (SPV) for firms as a legal entity to sell their assets (Eric \& Stosic, 2013).

\section{Added value measurements}

For measuring added value for the firms due to debt restructuring, we used the price to book value ratio. The market value of equity of a firm usually shows market expectations for their performance to generate cash. Book value consists of three aspects, the book value of assets, the book value of equity, and a book value of liabilities. Numbers provided from book value, generally from accounting measurement generated from financial statements. The book value of assets is a value of depreciated assets, while the book value of liabilities is a debt value when issued. The price to book ratio is often used in some analyses. Book value is not as volatile as the market value. If the firm's valuation measurement primarily used discounted cash flow (DCF), book value served as an alternative. Another reason is to prohibit overvaluation when comparing to another firm when using the price to book ratio. The price to book ratio is calculated by dividing the market price per share by the book value of equity per share (Damodaran, 2002). Using price to book ratio comes with disadvantages. If firms had negative equity, most likely, the valuation would also be negative (Damodaran, 2002). This study discussed the increased value of price to book ratio from negative to positive when firms had to restructure their debt-based methods already mentioned above.

\section{Previous studies on debt restructuring and ideal capital structure}

Mielcarz and Osiichuk (2017) conducted a study about the algorithm to determine the ideal structure for restructuring-needy firms based on average industrial, financial leverage. Mielcarz's algorithm will be based on the calculation to find every negative equity firm their ideal capital structure. Also, Kim and Wang (2020) examine debt restructuring by issuing equity-based securities based on South Korea's publicly traded firms from 2000 until 2013. They found that almost one-third of financially distressed firms tend to issue equity-based securities by swapping them with creditors to write off debtors. From this study only, we can conclude that firms tend to issue equity-based securities to recapitalize their asset while restructuring their debt. Nishihara and Shibata (2016) found that shareholder from financially distressed firms tends to have an option to choose between to have a massive restructuring or to liquidate the firms. This study concludes that share-holders tend to restructure their company to save them from bankruptcy or face liquidation, even with high restructuring costs and debt renegotiation.

Most of the shareholders tend to avoid selling their assets while restructuring their company's debt. Sepec and Grazl (2020) also examine renegotiation about debt to equity conversion on the firm's debt restructuring in Slovenia and their performance post-restructuring. This research found that debt to equity conversion limits the firm's bankruptcy after debt restructuring. This research also found that debt to equity conversion is an early best step to restructure firms and prevent firms from financial bankruptcy. Furthermore, Marie et al. (2013 found that firms tend to issue convertible bonds based on four theoretical models from the basis of issuing convertible bonds and also prevent it from another cost 
incurred while issuing the bonds. This research resulted in empirical studies about convertible bonds that found the motive of issuing convertible bonds and innovation about decisions financially.

\section{Material and Methods \\ Research strategy}

This section describes the steps followed in the study's execution and provides a brief justification for the research methods used. This section consists of research, data, and source of data, as well as the steps required to find the most effective debt restructuring method for each firm and industry.

This research using a quantitative approach and framework started from general to a specific object. Quantitative approach observed from calculations model to find the ideal capital structure for negative equity firms and to find a firm's performance to reach their ideal capital structure while using their debit restructuring methods. Data used for this research are financial statements of negative equity firms. On December 31st, 2019, there are 28 negative equity firms listed on the Indonesian Stock Exchange, data will be used only for one year. Firms will be divided from their industries and based on their size using total assets logarithm. In this research, data that we used are beta, weight average cost of capital (WACC), free cash flow to the firm (FCFF), cash, average industry beta, and the average leverage ratio of firms which are generated from Eikon - Thomson Reuters. Early data of firms can be seen in Table 1, which is consists of data of every firm. Every column consists of price per December 31st, 2019, Market value of equity, the market value of debt, and debt to equity ratio (DER), and price to book value $(\mathrm{P} / \mathrm{BV})$.

Table 1. List of firms with negative equity

\begin{tabular}{|c|c|c|c|c|c|}
\hline FIRMS & DER & $\begin{array}{l}\text { PRICE } \\
\text { (31 DEC } \\
\text { 2019) }\end{array}$ & $\mathbf{P} / \mathbf{B V}$ & $\begin{array}{c}\text { MARKET VALUE OF } \\
\text { DEBT (ON BILLION } \\
\text { RUPIAH }\end{array}$ & $\begin{array}{c}\text { MARKET VALUE } \\
\text { OF EQUITY (ON } \\
\text { BILLION RUPIAH) }\end{array}$ \\
\hline $\begin{array}{l}\text { PT JAKARTA KYOEI } \\
\text { STEEL WORKS TBK }\end{array}$ & $(1.3644)$ & 60.00 & $(9.07754)$ & - & 750.00 \\
\hline $\begin{array}{l}\text { PT ALUMINDO LIGHT } \\
\text { METAL INDUSTRY TBK }\end{array}$ & 786.9311 & 310.00 & 87.19228 & $8,529.73$ & $1,540.00$ \\
\hline $\begin{array}{l}\text { PT. MAGNA INVESTAMA } \\
\text { MANDIRI TBK }\end{array}$ & $(1.8453)$ & 50.00 & $(0.47724)$ & $1,059.72$ & $1,003.08$ \\
\hline PT SLJ GLOBAL TBK & 22.0141 & 52.00 & 3.27613 & $5,513.58$ & $32,223.28$ \\
\hline $\begin{array}{l}\text { PT DWI GUNA LAKSANA } \\
\text { TBK }\end{array}$ & $(19.5618)$ & 336.00 & $(62.87889)$ & $3,231.07$ & $8,709.80$ \\
\hline $\begin{array}{l}\text { ASIA PACIFIC FIBERS } \\
\text { TBK }\end{array}$ & $(1.2571)$ & 60.00 & $(0.01147)$ & $12,435.01$ & $88,265.46$ \\
\hline $\begin{array}{l}\text { PT MITRA INVESTINDO } \\
\text { TBK }\end{array}$ & $(5.9118)$ & 51.00 & $(6.18564)$ & 100.00 & 822.31 \\
\hline $\begin{array}{l}\text { PT SARANACENTRAL } \\
\text { BAJATAMA TBK }\end{array}$ & 10.2805 & 64.00 & 1.55283 & $2,407.99$ & $1,800.00$ \\
\hline PT INTRACO PENTA TBK & (17.6235) & 440.00 & $(5.97484)$ & $34,714.80$ & $1,669.82$ \\
\hline PT ONIX CAPITAL TBK & $(1.2966)$ & 230.00 & $(0.37384)$ & - & 546.40 \\
\hline $\begin{array}{l}\text { PT ICTSI JASA PRIMA } \\
\text { TBK }\end{array}$ & $(1.6156)$ & 62.00 & $(0.07727)$ & - & $4,484.73$ \\
\hline PT STEADY SAFE TBK & (7.9404) & 218.00 & $(2.60377)$ & - & $2,182.34$ \\
\hline $\begin{array}{l}\text { PT EXPRESS TRANSINDO } \\
\text { UTAMA TBK }\end{array}$ & $(2.0555)$ & 50.00 & $(0.67673)$ & $5,789.15$ & $6,145.60$ \\
\hline $\begin{array}{l}\text { PT WILTON MAKMUR IN- } \\
\text { DONESIA TBK }\end{array}$ & $(3.5797)$ & 238.00 & $(24.73119)$ & 19.94 & $38,843.98$ \\
\hline $\begin{array}{l}\text { PTLEYAND INTERNA- } \\
\text { TIONAL TBK }\end{array}$ & $(2.8570)$ & 50.00 & (22.98923) & - & $3,966.35$ \\
\hline $\begin{array}{l}\text { ZEBRA NUSANTARA } \\
\text { TBK }\end{array}$ & $(1.6138)$ & 99.00 & $(9.32798)$ & - & $1,016.46$ \\
\hline $\begin{array}{l}\text { TIGA PILAR SEJAHTERA } \\
\text { FOOD TBK }\end{array}$ & $(2.1273)$ & 168.00 & $(2.37633)$ & 291.09 & 94.87 \\
\hline $\begin{array}{l}\text { BAKRIE SUMATERA } \\
\text { PLANTATIONS TBK }\end{array}$ & $(2.5409)$ & 105.00 & (1.05805) & - & $14,848.59$ \\
\hline ARGO PANTES TBK & (1.9815) & 825.00 & $(1.15243)$ & $8,749.92$ & $10,048.51$ \\
\hline
\end{tabular}




\section{Data for iterations}

For this research, data collected consists of industry data, firm data, and market data. Industry data consists of industry beta, share of equity, share of debt, industry debt to equity ratio, market data consists of the risk-free rate, and the market risk premium of Indonesia. Furthermore, the firm's data consists of tax, firm's cash, cost of debt, cost of equity, and free cash flow to the firm. This iteration will be using Mielcarz and Osiichuck's (2017) iteration to find the ideal capital structure. The firm's data will be used for the end of 2019. Mielcarz's iteration is based on algorithm and formulation to find the ideal leverage ratio with perpetuity formulation. The value of firms is calculated:

$$
V=\frac{\mathrm{FCFF}}{\mathrm{WACC}}+\operatorname{Cash}(1)
$$

Whereas V is the firm's value, FCFF is free cash flow to the firm, and WACC is the Weighted average cost of capital, and cash is the firm's cash and cash equivalent on the firm's balance sheet. This formulation derives to:

$$
\begin{aligned}
& F C F F=\text { WACC } *(\mathrm{~V}-\text { Cash })(2) \\
& F C F F=W A C C *(E+D-\text { Cash })(3)
\end{aligned}
$$

Whereas $\mathrm{E}$ is the firm's shareholder's equity and D means the firm's debt. After obtaining these data, next, we calculate leveraged beta. Find leveraged beta can be found on this formulation (Hamada, 1972):

$\beta=\beta u *\left(1+(1-T) * \frac{D}{E}\right)(4)$

Whereas, $\beta$ means the firm's beta. $\beta u$ means unlevered beta, T means tax rate and $\mathrm{D} / \mathrm{E}$ means leverage ratio and the calculation for finding unlevered beta for corrected cash as found below (Damodaran, 2010):

$$
\begin{aligned}
& \beta u=\beta u c f c *\left(1-\frac{\text { Cash }}{V}\right) \\
& \beta u=\beta u c f c *\left(1-\frac{\text { Cash }}{E+D}\right)
\end{aligned}
$$

Whereas, $\beta$ ucfc is unlevered beta corrected for cash. After finding unlevered beta is finding WACC. WACC formulation can be shown below:

$$
\begin{aligned}
& W A C C=K e *\left(\frac{E}{D+E}\right)+K d *(1-\mathrm{T}) \\
& *\left(\frac{\text { Cash }}{E+D}\right)(7)
\end{aligned}
$$

Whereas $\mathrm{Ke}$ is the cost of equity, $\mathrm{Kd}$ is the cost of debt, with the input data consists Rf means riskfree rate, Rp means risk premium, $\beta$ ucfc, Ds means industry's leverage ratio, Ud means the market value of debt, Ue market value equity, T means tax rate, Cash and Free cash flow to the firm. Data that will be used on iteration will be shown in Table 2 . 
Table 2. Data Needed for Iterations

\begin{tabular}{|c|c|c|c|c|c|c|c|c|c|c|}
\hline FIRMS & $\begin{array}{c}\text { CASH IN } \\
\text { MIL- } \\
\text { LIONS } \\
\text { RUPIAH }\end{array}$ & $\begin{array}{c}\text { UN- } \\
\text { LEVERED } \\
\text { BETA }\end{array}$ & $\begin{array}{l}\text { LEV- } \\
\text { ERED } \\
\text { BETA }\end{array}$ & $\begin{array}{c}\text { COST } \\
\text { OF } \\
\text { EQ- } \\
\text { UITY }\end{array}$ & $\begin{array}{c}\text { COS } \\
\text { T OF } \\
\text { DEB } \\
\text { T }\end{array}$ & $\begin{array}{l}\text { SHARE } \\
\text { OF } \\
\text { DEBT }\end{array}$ & $\begin{array}{l}\text { SHARE } \\
\text { OF EQ- } \\
\text { UITY }\end{array}$ & $\begin{array}{c}\text { FCF IN } \\
\text { MIL- } \\
\text { LIONS } \\
\text { RUPIAH }\end{array}$ & $\begin{array}{l}\text { INDUS- } \\
\text { TRY DER }\end{array}$ & WACC \\
\hline $\begin{array}{l}\text { PT JAKARTA } \\
\text { KYOEI STEEL } \\
\text { WORKS TBK }\end{array}$ & 12,105 & 1.00 & -0.02 & 0.07 & 0.05 & $0.00 \%$ & $100.00 \%$ & 97,960 & 1.87 & $7.04 \%$ \\
\hline $\begin{array}{l}\text { PT ALUMINDO } \\
\text { LIGHT METAL IN- } \\
\text { DUSTRY TBK }\end{array}$ & 7,945 & 0.64 & 378.37 & 9.11 & 0.05 & $84.71 \%$ & $15.29 \%$ & )$^{(2,690,160}$ & 1.87 & $142.24 \%$ \\
\hline $\begin{array}{l}\text { PT. MAGNA IN- } \\
\text { VESTAMA MAN- } \\
\text { DIRI TBK }\end{array}$ & 416 & -1.04 & 0.40 & 0.08 & 0.05 & $51.37 \%$ & $48.63 \%$ & $(120,350)$ & 0.14 & $5.65 \%$ \\
\hline $\begin{array}{l}\text { PT SLJ GLOBAL } \\
\text { TBK }\end{array}$ & 30,503 & 1.06 & 18.56 & 0.51 & 0.05 & $14.61 \%$ & $85.39 \%$ & $(67,939)$ & 0.7 & $44.44 \%$ \\
\hline $\begin{array}{l}\text { PT DWI GUNA } \\
\text { LAKSANA TBK }\end{array}$ & 59,854 & 0.45 & -6.15 & $(0.08)$ & 0.05 & $27.06 \%$ & $72.94 \%$ & $\begin{array}{l}(6,959,110 \\
)\end{array}$ & 0.79 & $-4.63 \%$ \\
\hline $\begin{array}{l}\text { ASIA PACIFIC FI- } \\
\text { BERS TBK }\end{array}$ & 1,387 & 0.19 & 0.01 & 0.07 & 0.05 & $12.35 \%$ & $87.65 \%$ & 97,055 & 0.7 & $6.66 \%$ \\
\hline $\begin{array}{l}\text { PT MITRA IN- } \\
\text { VESTINDO TBK }\end{array}$ & 6,836 & 1.00 & -3.43 & $(0.01)$ & 0.05 & $10.84 \%$ & $89.16 \%$ & $(137,610)$ & 0.79 & $-0.62 \%$ \\
\hline $\begin{array}{l}\text { PT SARANACEN- } \\
\text { TRAL BAJATAMA } \\
\text { TBK }\end{array}$ & 17,242 & 0.69 & 6.01 & 0.21 & 0.05 & $57.22 \%$ & $42.78 \%$ & 621,530 & 1.87 & $11.11 \%$ \\
\hline $\begin{array}{l}\text { PT INTRACO } \\
\text { PENTA TBK }\end{array}$ & 55,929 & 0.39 & -4.76 & $(0.04)$ & 0.05 & $95.41 \%$ & $4.59 \%$ & $2,298,470$ & 1.488 & $3.02 \%$ \\
\hline $\begin{array}{l}\text { PT ONIX CAPITAL } \\
\text { TBK }\end{array}$ & 7,583 & -0.96 & -0.03 & 0.07 & 0.05 & $0.00 \%$ & $100.00 \%$ & $(80,000)$ & 0.3 & $7.04 \%$ \\
\hline $\begin{array}{l}\text { PT ICTSI JASA } \\
\text { PRIMA TBK }\end{array}$ & 2,180 & 0.62 & -0.13 & 0.07 & 0.05 & $0.00 \%$ & $100.00 \%$ & 542,122 & 0.61 & $6.79 \%$ \\
\hline $\begin{array}{l}\text { PT STEADY SAFE } \\
\text { TBK } \\
\text { PT EXPRESS }\end{array}$ & 5,726 & 0.67 & -3.32 & $(0.01)$ & 0.05 & $0.00 \%$ & $100.00 \%$ & $(183,890)$ & 0.61 & $-0.83 \%$ \\
\hline $\begin{array}{l}\text { TRANSINDO } \\
\text { UTAMA TBK } \\
\text { PT WILTON }\end{array}$ & 19,514 & -0.99 & 0.54 & 0.08 & 0.05 & $48.51 \%$ & $51.49 \%$ & 280,600 & 0.61 & $5.95 \%$ \\
\hline $\begin{array}{l}\text { MAKMUR INDO- } \\
\text { NESIA TBK }\end{array}$ & 2,560 & 0.97 & -1.63 & 0.03 & 0.05 & $0.05 \%$ & $99.95 \%$ & $(755,050)$ & 0.79 & $3.19 \%$ \\
\hline $\begin{array}{l}\text { PTLEYAND IN- } \\
\text { TERNATIONAL } \\
\text { TBK }\end{array}$ & 998 & 0.00 & 0.00 & 0.07 & 0.05 & $0.00 \%$ & $100.00 \%$ & 144,840 & 1.87 & $7.10 \%$ \\
\hline $\begin{array}{l}\text { ZEBRA NUSAN- } \\
\text { TARA TBK }\end{array}$ & 151 & 0.02 & 0.00 & 0.07 & 0.05 & $0.00 \%$ & $100.00 \%$ & (69) & 0.61 & $7.09 \%$ \\
\hline $\begin{array}{l}\text { TIGA PILAR SE- } \\
\text { JAHTERA FOOD } \\
\text { TBK }\end{array}$ & 55,065 & 1.00 & -0.60 & 0.06 & 0.05 & $75.42 \%$ & $24.58 \%$ & 83,745 & 0.556 & $3.94 \%$ \\
\hline $\begin{array}{l}\text { BAKRIE SU- } \\
\text { MATERA PLAN- } \\
\text { TATIONS TBK }\end{array}$ & 78,895 & 0.70 & -0.63 & 0.06 & 0.05 & $0.00 \%$ & $100.00 \%$ & )$^{(1,847,234}$ & 0.744 & $5.58 \%$ \\
\hline $\begin{array}{l}\text { ARGO PANTES } \\
\text { TBK }\end{array}$ & 2,560 & 1.00 & -0.49 & 0.06 & 0.05 & $46.55 \%$ & $53.45 \%$ & $(497,199)$ & 0.701 & $4.75 \%$ \\
\hline
\end{tabular}

Source: Eikon, Thomson-Reuters with own elaboration (202

\section{Iteration process and result}

For finding the ideal capital structure, we used Mielcarz and Osiichuk's iteration algorithm. With the data found above, the next step will find the ideal capital structure using Mielcarz's algorithm. The initial value of shareholder's equity and debt is described:

$D n=\operatorname{Dcomp}(8)$

$E n=E \operatorname{comp}(9)$

Whereas $n$ is the number of iterations, which is Dn is debt iteration number-n, En is equity iteration number -n, Dcomp means the firm's debt position, and Ecomp means the firm's equity position. After finding such a result. The next step would be finding iteration unlevered beta with formulation: 
$\beta U n=\beta \sec *\left(1-\frac{C a s h}{E n+D n}\right)$

Whereas $\beta U n$ is unlevered beta results of iteration, $\beta$ sec is unlevered beta corrected for cash for the industry. So with that result that finding levered beta on iteration process with formulation below:

$\beta n=\beta u n *(1+(1-T) * D s)(11)$

Whereas $\beta \mathrm{n}$ is unlevered beta results of iteration, is unlevered beta corrected for cash for the industry. So, with that result that is finding levered beta on the iteration process with formulation below:

$K e n=R f+\beta n * R p(12)$

Whereas Ken is the cost of equity iteration number-n, $\mathrm{Rf}$ is the risk-free rate and $\mathrm{Rp}$ is the market risk premium from the market. With the cost of equity already found, the next step would be an iteration of WACC, which can be found with the formulation:

$W A C C n=\operatorname{Ken} *\left(\frac{E}{D+E}\right)+K d *(1-\mathrm{T})$

* $\left(\frac{\text { Cash }}{E+D}\right)$

Whereas WACCn means WACC iteration number-n, and Kd means the firm's cost of debt. With the results found. The next step would be calculating the firm's equity and debt for the next iterations with iterations number $\mathrm{n}+1$ with the formulation:

$D n+1=\frac{D s *(E n+D n)}{1+D s}$

Whereas $\mathrm{Dn}+1$ is debt iteration number $\mathrm{n}+1$

$E n+1=\frac{F C F F}{W A C C n+1}+C a s h-D n+1$

Whereas En +1 is the shareholder's equity number $n+1$. Those equity and debt are needed to find the ideal leverage ratio. The iteration process is needed and will be simplified to one formula. Those formulas would be described:

$s 1=(1+(1-T) * D s)(16)$

$s 2 n=\frac{D}{E+D} * K d *(I-T)$

With the results of iterations number $n+1$, we can find the formulation to find equity:

$E n+1=$ 


$$
\begin{gathered}
\frac{F C F F}{\frac{E n}{E n+D n} *} \\
\left(R f+\beta s e c *\left(\begin{array}{c}
\text { Cash } \\
+s n+D n
\end{array}\right) * s 1 * R p\right) \\
+ \text { Cash }-\frac{D s *(E n+D n)}{1+D s}(18)
\end{gathered}
$$

So, with assumptions below:

$E n \rightarrow E, D n \rightarrow D, n \rightarrow \infty$

With those assumptions above we found:

$D=\frac{D s *(E+D)}{1+D s}$

And there is changing variables found:

$u E=\frac{E}{E+D}(20)$

$u D=\frac{D}{E+D}$

Whereas $\mathrm{uE}$ means weighted shareholder's equity from industry and $\mathrm{uD}$ means weighted liability from the industry. With that, the leverage ratio from firms will be converted to the industry's leverage ratio. The firm's shareholder's equity and debt from the capital structure will be described as $\mathrm{uE}$ and uD. Which gives the next formulation:

$s 1=(1+(1-T) * D s)(22)$

$s 2=u D * K d *(1-T)(23)$

$w 1=u E *(R f+R p * \beta \sec * s 1)+s 2(24)$

$w 2=u E *(R p * \beta \sec * s 1 * \operatorname{cash})(25)$

Whereas $\mathrm{s} 1, \mathrm{~s} 2, \mathrm{w} 1$, and $\mathrm{w} 2$ is the substitution variable. With those variables, the next step to finding formulation:

$=\frac{F C F F}{w 1-\frac{w 2}{E *(1+D s)}}+\operatorname{Cash}-D(26)$ 
$E=\frac{F C F F * E *(1+D s)}{w 1 * E+w 1 * D s * E-w 2}+\operatorname{Cash}-E$

*Ds (27)

$E *(1+D s)=\frac{F C F F * E *(1+D s)}{w 1 * E *(1+D s)-w 2}$

$+\operatorname{Cash}(28)$

$E^{2} *(1+D s)^{2} * w 1-E *(1+D s)$

$*(w 2+F C F F+w 1 * C a s h)$

$+w 2 * \operatorname{cash}=0(29)$

With assumptions below:

$x=E *(1+D s)(30)$

Whereas, we found formulation below:

$x^{2} * w 1-x *(w 2+F C F F+w 1 * C a s h)$

$+w 2 * \operatorname{cash}=0(31)$

Moreover, with variable substitution, we can find the formulation below:

$a=w 1, a \neq 0(32)$

$b=w 2+F C F F+w 1 x \operatorname{Cash}(33)$

$c=w 2 \times \operatorname{Cash}(34)$

Whereas, the value of a,b, I, and C with variable substitution results to find formulation which can found below:

$a x x^{2}+b * x+c=0$

If the discriminant of those formulas is not negative, then those formulations have an answer. For finding those formula needed to find $\mathrm{x}$ value from square roots of quadratic equations. For finding the square root, we use the formulation below:

$x 1,2$

$\left(\begin{array}{c}(\mathrm{w} 2+\mathrm{FCFF}+\mathrm{w} 1 * \text { Cash }) \\ \pm\end{array}\right.$
$=\frac{\sqrt{\begin{array}{c}(\mathrm{w} 2+\mathrm{FCFF}+\mathrm{w} 1 * \text { Cash })^{2} \\ -4 * w 1 * w 2 * \text { cash }\end{array}}}{2 * w 1}(36)$ 

below:

After finding the square roots, we can find new shareholder's equity and debt with the formulation $E=\frac{x}{(1+D s)}$

With the formulations above, we found two values of debt and the value of shareholder's equity, and with that formulation, we used value above zero after finding the result of new percentage debt and shareholder's equity. Table 3 is one example of how iteration worked on one firm, and Table 4 is the results of every firm's iteration, which found a new portion of debt and shareholder's equity found, which also found the most effective ideal value of shareholder's equity and debt of every firm. With that result of the new value of the liability, we can find the most effective amount of debt needed to be restructured. If a firm's debt restructuring capability did not meet the most effective ideal value, which means, we used the new debt value based on their capabilities to calculate their price to book value $(\mathrm{P} / \mathrm{BV})$ and debt to equity ratio (DER).

Table 3. Iteration results

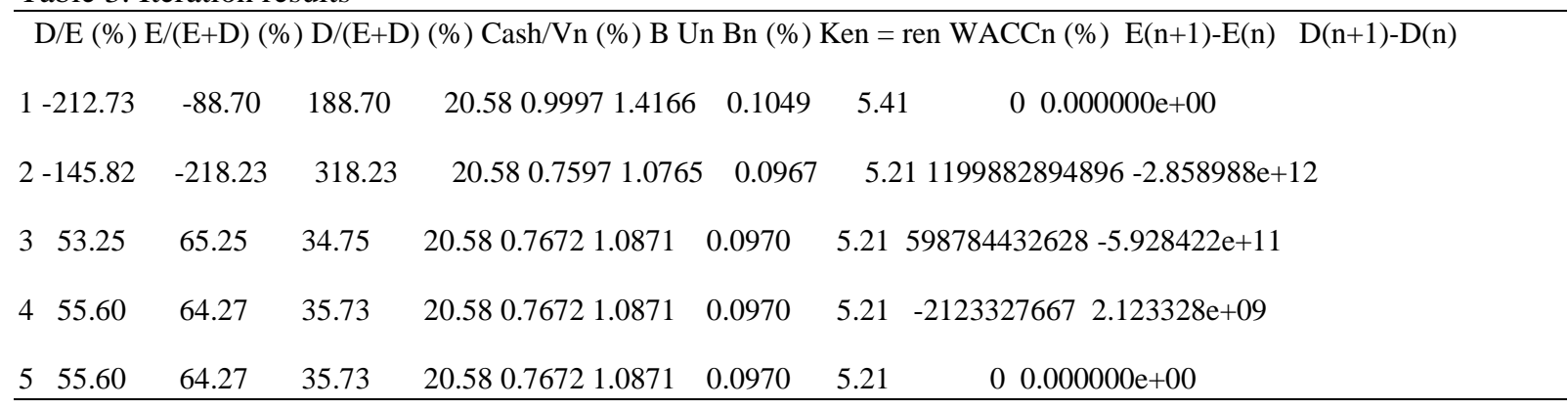

Source: Own elaboration (2020)

Table 4. Iterations result of every firm

\begin{tabular}{|c|c|c|c|c|c|}
\hline Company & $\begin{array}{l}\text { NEW POR- } \\
\text { TION OF } \\
\text { DEBT }\end{array}$ & $\begin{array}{l}\text { NEW POR- } \\
\text { TION OF } \\
\text { EQUITY }\end{array}$ & $\begin{array}{l}\text { TARGET EQ- } \\
\text { UITY }\end{array}$ & $\begin{array}{l}\text { TARGET LIA- } \\
\text { BILITY }\end{array}$ & $\begin{array}{l}\text { LIABILITIES } \\
\text { NEEDED TO RE- } \\
\text { STRUCTURING }\end{array}$ \\
\hline $\begin{array}{l}\text { PT JAKARTA KYOEI } \\
\text { STEEL WORKS TBK }\end{array}$ & $65.16 \%$ & $34.84 \%$ & $62,930,732,964$ & $117,697,088,402$ & $558,659,704,232$ \\
\hline $\begin{array}{l}\text { PT ALUMINDO } \\
\text { LIGHT METAL IN- } \\
\text { DUSTRY TBK }\end{array}$ & $65.16 \%$ & $34.84 \%$ & $601,216,329,307$ & $1,124,433,295,571$ & $599,026,227,160$ \\
\hline $\begin{array}{l}\text { PT. MAGNA INVES- } \\
\text { TAMA MANDIRI }\end{array}$ & $12.28 \%$ & $87.72 \%$ & $77,929,129,027$ & $10,909,367,356$ & $183,021,226,994$ \\
\hline TBK & & & & & \\
\hline PT SLJ GLOBAL TBK & $41.18 \%$ & $58.82 \%$ & $856,642,195,281$ & $599,736,919,444$ & $793,360,269,396$ \\
\hline $\begin{array}{l}\text { PT DWI GUNA LAK- } \\
\text { SANA TBK }\end{array}$ & $44.13 \%$ & $55.87 \%$ & $482,654,243,478$ & $381,233,788,522$ & $529,195,457,478$ \\
\hline $\begin{array}{l}\text { ASIA PACIFIC FI- } \\
\text { BERS TBK }\end{array}$ & $41.18 \%$ & $58.82 \%$ & $1,974,025,475,732$ & $1,382,019,195,693$ & $15,025,786,323,772$ \\
\hline $\begin{array}{l}\text { PT MITRA IN- } \\
\text { VESTINDO TBK }\end{array}$ & $44.13 \%$ & $55.87 \%$ & $31,937,452,730$ & $25,226,414,694$ & $43,575,552,763$ \\
\hline To be continued & & & & & \\
\hline
\end{tabular}




\begin{tabular}{|c|c|c|c|c|c|}
\hline PT SARANACEN- & $65.16 \%$ & $34.84 \%$ & $291,565,777,662$ & $545,304,996,339$ & $217,378,583,946$ \\
\hline \multicolumn{6}{|l|}{ TRAL BAJATAMA } \\
\hline \multicolumn{6}{|l|}{ TBK } \\
\hline PT INTRACO PENTA & $40.19 \%$ & $59.81 \%$ & $2,425,355,310,000$ & $1,629,744,690,000$ & $2,669,293,310,000$ \\
\hline \multicolumn{6}{|l|}{ TBK } \\
\hline \multicolumn{6}{|l|}{ TBK } \\
\hline PT ICTSI JASA & $37.89 \%$ & $62.11 \%$ & $180,137,355,713$ & $109,892,197,842$ & $651,259,975,858$ \\
\hline \multicolumn{6}{|l|}{ PRIMA TBK } \\
\hline $\begin{array}{l}\text { PT STEADY SAFE } \\
\text { TBK }\end{array}$ & \multicolumn{5}{|c|}{$\mathrm{TBK}$} \\
\hline PT EXPRESS & $37.89 \%$ & $62.11 \%$ & $297,671,697,084$ & $181,593,633,916$ & $751,734,246,084$ \\
\hline \multicolumn{6}{|l|}{ TRANSINDO UTAMA } \\
\hline \multicolumn{6}{|l|}{ TBK } \\
\hline PT WILTON & $44.13 \%$ & $55.87 \%$ & $215,505,472,185$ & $170,221,164,982$ & $365,031,120,952$ \\
\hline \multicolumn{6}{|l|}{ MAKMUR INDONE- } \\
\hline $\begin{array}{l}\text { PTLEYAND INTER- } \\
\text { NATIONAL TBK }\end{array}$ & \multicolumn{4}{|c|}{ NATIONAL TBK } & $142,076,032,319$ \\
\hline $\begin{array}{l}\text { ZEBRA NUSANTARA } \\
\text { TBK }\end{array}$ & \multicolumn{4}{|c|}{ TBK } & $12,550,552,618$ \\
\hline $\begin{array}{l}\text { TIGA PILAR SE- } \\
\text { JAHTERA FOOD TBK }\end{array}$ & \multicolumn{4}{|c|}{ JAHTERA FOOD TBK } & $2,859,037,448,200$ \\
\hline BAKRIE SUMATERA & $42.66 \%$ & $57.34 \%$ & $4,814,760,670,800$ & $3,582,101,329,200$ & $10,264,171,670,800$ \\
\hline \multicolumn{6}{|l|}{ PLANTATIONS TBK } \\
\hline ARGO PANTES TBK & $41.21 \%$ & $58.79 \%$ & $693,123,055,687$ & $485,858,158,273$ & $1,894,291,389,272$ \\
\hline
\end{tabular}

Source: Own elaboration (2020)

\section{Assumptions}

The ideal capital structure corresponds to the firm's industrial average based on good corporate governance, making ideal decisions regarding the change in the capital structure.

\section{Restructuring methods}

After we find the ideal capital structure from the data, the next step is to find the most effective debt restructuring methods for these negative equity firms. For debt to equity swap, the next step is finding a loan instrument from creditors to convert it into equity, so the creditors become co-owners of the firms. (Eric \& Stosic, 2013). Convertible bonds are hybrid bonds. Every bondholder has a right to convert their bonds into equity (Stein, 1992). For this reason, we need to give an assumption for every bondholder to convert their bond into shares. Another debt restructuring methods are debt to asset swap and debt repayment agreements. Debt to asset swap is swapping assets and sell them to creditors to write off their portion of the debt (Eric \& Stosic, 2013). Debt repayment agreements are a debt restructuring method to delay their payment for the time being (Fuady, 2001). This method changes inclusion on financial statements, where a loan from the third party that already meets due payment is being delayed.

\section{Finding the most effective restructuring methods}

To find the most effective debt restructuring methods from every firm is to use a decision matrix. A decision matrix is an informational graph to help systematically analyzing every connection of information. (Shafer, 1976). A decision matrix would be influential to find the most effective method. The most effective method is based on the criteria of results gained from every calculation for every 
debt restructuring method, which consists of price to book ratio and debt to equity ratio. Assumptions in this study are based on the objectives, to find the ideal capital structure of every firm and identify the added value. The debt to equity ratio is computed by simply dividing the total debt of the firm, including current liabilities by its shareholders' equity (Horne \& Wachowicz, 2008). If the equity conversion is not attained the ideal amount of equity, it will have a higher DER. With the result, the weighted value of DER would be the denominator. To identify added value we use price to book value (P/BV), as one of the significant values of the decision matrix, based.

\section{Results and Discussion}

\section{Analysis of debt restructuring method to capital structure and its impact on firms'value-added}

For analyzing the data, Firms will be treated with each of the debt restructuring methods to find changes in debt to equity ratio (DER) and their price to book value (P/BV). Table 5 and Table 6 describe every P/BV and DER after going through debt restructuring. There are four methods with a weighted total value, where the highest value is the ideal debt restructuring method for firms. The table above explains whether there is a change in company value and changes in its capital structure after debt restructuring. The debt-to-equity ratio (DER) value indicates the company's ability to achieve the ideal capital structure and see the price to book value (P / BV) to see the company's added value. These two components will be the company's major decision to choose the right debt restructuring method.

Table 5 Simulation results of debt restructuring methods (firms)

\begin{tabular}{|c|c|c|c|c|c|c|c|c|c|c|c|c|}
\hline \multirow{2}{*}{ FIRMS } & \multicolumn{3}{|c|}{$\begin{array}{l}\text { DEBT TO EQUITY SWAP } \\
\text { (WA) }\end{array}$} & \multicolumn{3}{|c|}{$\begin{array}{l}\text { CONVERTIBLE BONDS } \\
\text { (WA) }\end{array}$} & \multicolumn{3}{|c|}{$\begin{array}{c}\text { DEBT TO ASSET SWAP } \\
\text { (WA) }\end{array}$} & \multicolumn{3}{|c|}{$\begin{array}{c}\text { REPAYMENT AGREEMENT } \\
\text { (WA) }\end{array}$} \\
\hline & PBV & DER & $\begin{array}{l}\text { TO- } \\
\text { TAL }\end{array}$ & PBV & DER & TOTAL & PBV & DER & TOTAL & PBV & DER & TOTAL \\
\hline $\begin{array}{l}\text { PT BAKRIE SUMATRA } \\
\text { PLANTATIONS TBK }\end{array}$ & 0.37 & 0.71 & 1.08 & 0.31 & 0.35 & 0.66 & 0.00 & -0.40 & -0.40 & 0.00 & -0.39 & -0.39 \\
\hline $\begin{array}{l}\text { PT TIGA PILAR SE- } \\
\text { JAHTERA FOOD TBK }\end{array}$ & 4.43 & 0.34 & 4.77 & 2.33 & 0.34 & 2.67 & 0.00 & -0.48 & -0.48 & 0.00 & -0.47 & -0.47 \\
\hline PT SLJ GLOBAL TBK & -8.87 & 0.80 & -8.06 & -8.78 & 0.43 & -8.35 & 0.00 & 0.05 & 0.05 & 0.00 & 0.05 & 0.05 \\
\hline $\begin{array}{l}\text { PT ICTSI JASA PRIMA } \\
\text { TBK }\end{array}$ & 0.84 & 1.64 & 2.48 & 0.84 & 0.24 & 1.07 & 0.00 & -0.64 & -0.64 & 0.00 & -0.62 & -0.62 \\
\hline PT ONIX CAPITAL TBK & 8.58 & 1.03 & 9.61 & 6.04 & 0.18 & 6.21 & 0.00 & -0.90 & -0.90 & 0.00 & -0.77 & -0.77 \\
\hline $\begin{array}{l}\text { PT INTRACO PETRA } \\
\text { TBK }\end{array}$ & 19.88 & 1.49 & 21.37 & 19.88 & 0.56 & 20.45 & 0.00 & -0.07 & -0.07 & 0.00 & -0.06 & -0.06 \\
\hline $\begin{array}{l}\text { PT MAGNA INVES- } \\
\text { TAMA MANDIRI TBK }\end{array}$ & 3.71 & 2.90 & 6.61 & 3.36 & 0.40 & 3.76 & 0.00 & -0.54 & -0.54 & 0.00 & -0.54 & -0.54 \\
\hline $\begin{array}{l}\text { PT LEYAND INTERNA- } \\
\text { TIONAL TBK }\end{array}$ & -1.12 & -0.32 & -1.43 & 17.56 & 0.23 & 17.78 & 0.00 & -0.35 & -0.35 & 0.00 & -0.35 & -0.35 \\
\hline $\begin{array}{l}\text { PT ASIA PACIFIC FI- } \\
\text { BERS TBK }\end{array}$ & 0.31 & 0.95 & 1.26 & 0.26 & 0.12 & 0.38 & 0.00 & -0.80 & -0.80 & 0.00 & -0.80 & -0.80 \\
\hline PT ARGO PANTES TBK & 6.12 & 1.37 & 7.50 & 6.03 & 0.29 & 6.32 & -3.42 & -0.52 & -3.94 & -3.42 & -0.50 & -3.93 \\
\hline $\begin{array}{l}\text { PT DWI GUNA LAK- } \\
\text { SANA TBK }\end{array}$ & 220.38 & 0.47 & 220.85 & 206.83 & 0.53 & 207.36 & 0.00 & -0.06 & -0.06 & 0.00 & -0.06 & -0.06 \\
\hline $\begin{array}{l}\text { PT MITRA INVESTINDO } \\
\text { TBK }\end{array}$ & - & -0.03 & - & 25.32 & 0.46 & 25.78 & 0.00 & -0.20 & -0.20 & 0.00 & -0.17 & -0.17 \\
\hline $\begin{array}{l}\text { PT WILTON MAKMUR } \\
\text { INDONESIA TBK }\end{array}$ & 112.07 & 3.16 & 115.22 & 125.67 & 0.40 & 126.07 & 0.00 & -0.29 & -0.29 & 0.00 & -0.28 & -0.28 \\
\hline $\begin{array}{llr}\text { PT } & \text { JAKARTA } & \text { KYOEI } \\
\text { STEEL } & \text { WORKS } & \text { TBK } \\
(\text { JKSW) } & & \end{array}$ & 241.75 & 0.53 & 242.29 & 241.75 & 0.09 & 241.85 & 0.00 & -0.80 & -0.80 & 0.00 & -0.73 & -0.73 \\
\hline $\begin{array}{l}\text { PT ALUMINDO METAL } \\
\text { LIGHT INDUSTRY TBK } \\
\text { (ALMI) }\end{array}$ & - & 0.53 & $\begin{array}{l}- \\
260.09\end{array}$ & - & 0.35 & -260.28 & 0.00 & 0.00 & 0.00 & 0.00 & 0.00 & 0.00 \\
\hline $\begin{array}{l}\text { PT SARANACENTRAL } \\
\text { BAJATAMA TBK (BAJA) }\end{array}$ & -3.47 & 0.53 & -2.94 & -3.47 & 0.38 & -3.09 & 0.00 & 0.10 & 0.10 & 0.00 & 0.10 & 0.10 \\
\hline $\begin{array}{lr}\text { PT } & \text { EXPRESS } \\
\text { TRANSINDO } & \text { UTAMA } \\
\text { TBK (TAXI) } & \\
\text { To be continued } & \end{array}$ & 5.29 & 1.43 & 6.73 & 5.13 & 1.51 & 6.64 & 0.00 & -0.51 & -0.51 & 0.00 & -0.49 & -0.49 \\
\hline
\end{tabular}




\begin{tabular}{|c|c|c|c|c|c|c|c|c|c|c|c|c|}
\hline $\begin{array}{l}\text { PT STEADY SAFE TBK } \\
\text { (SAFE) }\end{array}$ & 21.57 & 1.62 & 23.19 & 21.56 & 0.54 & 22.10 & 2.13 & -0.30 & 1.84 & 2.13 & -0.13 & 2.01 \\
\hline $\begin{array}{l}\text { PT ZEBRA NUSANTARA } \\
\text { TBK ZBRA }\end{array}$ & -11.67 & -0.51 & -12.18 & 72.85 & 0.24 & 73.08 & 0.00 & -0.63 & -0.63 & 0.00 & -0.62 & -0.62 \\
\hline
\end{tabular}

Source: Own elaboration (2020)

\section{Firms}

As shown in Table 5, PT Bakrie Sumatra Plantations Tbk, PT Tiga Pilar Sejahtera Food Tbk, PT ICTSI Jasa Prima Tbk, PT ONIX Capital Tbk, PT Intraco Petra, PT Magna Investama Mandiri Tbk, PT Asia Pacific Fibers Tbk, PT Argo Pantes Tbk, PT Dwi Guna Laksana, PT Jakarta Kyoei Steel Works and PT Steady Safe Tbk have their the highest weighted value debt restructuring is debt to equity swap method. PT Leyland International Tbk, PT Mitra Investindo Tbk, PT Wilton Makmur Indonesia Tbk, and PT Zebra Nusantara Tbk would be ideal if they issued a convertible bond for restructuring their debt. Furthermore, PT SLJ Global Tbk, PT Alumindo Light Industry Tbk, PT Saran Central Bajatama Tbk, and PT Express Transindo Utama Tbk would be ideal if they used debt to asset swap as their debt restructuring method. Arguing that firms most likely have better positions after debt restructuring using debt to equity conversion (Sepec and Grazl, 2020) is evidenced in this study. Most firms tend to have their best performance, in terms of added value while using debt to equity conversion methods. Which consists of debt to an equity swap and issuing convertible bonds.

Table 6. Simulation results of debt restructuring methods (industries)

\begin{tabular}{|c|c|c|c|c|c|c|c|c|c|c|c|c|c|c|}
\hline \multirow{2}{*}{ Company } & \multicolumn{3}{|c|}{$\begin{array}{c}\text { Debt to Equity } \\
\text { Swap (WA) }\end{array}$} & \multicolumn{3}{|c|}{$\begin{array}{c}\text { Convertible bonds } \\
\text { (WA) }\end{array}$} & \multicolumn{3}{|c|}{$\begin{array}{l}\text { Debt to Asset } \\
\text { Swap (WA) }\end{array}$} & \multicolumn{3}{|c|}{$\begin{array}{c}\text { Repayment } \\
\text { Agreement (WA) }\end{array}$} & \multirow{2}{*}{$\begin{array}{c}\text { High- } \\
\text { est } \\
\text { Point }\end{array}$} & \multirow{2}{*}{$\begin{array}{l}\text { Recom- } \\
\text { mended } \\
\text { Action }\end{array}$} \\
\hline & PBV & DER & Total & PBV & DER & Total & PBV & DER & Total & PBV & DER & Total & & \\
\hline Fishing and Farming & 0.37 & 0.71 & 1.08 & 0.31 & 0.35 & 0.66 & 0.00 & -0.40 & -0.40 & 0.00 & -0.39 & -0.39 & 1.08 & $\begin{array}{l}\text { Debt-to-Eq- } \\
\text { uity Swap }\end{array}$ \\
\hline Food Processing & 4.43 & 0.34 & 4.77 & 2.33 & 0.34 & 2.67 & 0.00 & -0.48 & -0.48 & 0.00 & -0.47 & -0.47 & 4.77 & $\begin{array}{l}\text { Debt-to-Eq- } \\
\text { uity Swap }\end{array}$ \\
\hline $\begin{array}{l}\text { Forest and Wood } \\
\text { Products }\end{array}$ & -8.87 & 0.80 & -8.06 & -8.78 & 0.43 & -8.35 & 0.00 & 0.05 & 0.05 & 0.00 & 0.05 & 0.05 & 0.05 & $\begin{array}{l}\text { Debt-to-As- } \\
\text { set Swap }\end{array}$ \\
\hline $\begin{array}{l}\text { Marine Port Ser- } \\
\text { vices }\end{array}$ & 0.84 & 1.64 & 2.48 & 0.84 & 0.24 & 1.07 & 0.00 & -0.64 & -0.64 & 0.00 & -0.62 & -0.62 & 2.48 & $\begin{array}{l}\text { Debt-to-Eq- } \\
\text { uity Swap }\end{array}$ \\
\hline $\begin{array}{l}\text { Banking and Invest- } \\
\text { ment Services }\end{array}$ & 8.58 & 1.03 & 9.61 & 6.04 & 0.18 & 6.21 & 0.00 & -0.90 & -0.90 & 0.00 & -0.77 & -0.77 & 9.61 & $\begin{array}{l}\text { Debt-to-Eq- } \\
\text { uity Swap }\end{array}$ \\
\hline Industrial Machinery & 19.88 & 1.49 & 21.37 & 19.88 & 0.56 & 20.45 & 0.00 & -0.07 & -0.07 & 0.00 & -0.06 & -0.06 & 21.37 & $\begin{array}{l}\text { Debt-to-Eq- } \\
\text { uity Swap }\end{array}$ \\
\hline $\begin{array}{l}\text { Investment Holding } \\
\text { Company }\end{array}$ & 3.71 & 2.90 & 6.61 & 3.36 & 0.40 & 3.76 & 0.00 & -0.54 & -0.54 & 0.00 & -0.54 & -0.54 & 6.61 & $\begin{array}{l}\text { Debt-to-Eq- } \\
\text { uity Swap }\end{array}$ \\
\hline Electric Utilities & -1.12 & -0.32 & -1.43 & 17.56 & 0.23 & 17.78 & 0.00 & -0.35 & -0.35 & 0.00 & -0.35 & -0.35 & 17.78 & $\begin{array}{l}\text { Convertible } \\
\text { Bonds }\end{array}$ \\
\hline Oil and Gas & 6.43 & 2.32 & 8.76 & 6.29 & 0.41 & 6.70 & -3.42 & -1.32 & -4.74 & -3.42 & -1.30 & -4.72 & 8.76 & $\begin{array}{l}\text { Debt-to-Eq- } \\
\text { uity Swap }\end{array}$ \\
\hline $\begin{array}{l}\text { Textile and Leather } \\
\text { Goods }\end{array}$ & 219.16 & 3.60 & 222.76 & 357.82 & 1.40 & 359.21 & 0.00 & -0.55 & -0.55 & 0.00 & -0.50 & -0.50 & 359.21 & $\begin{array}{l}\text { Convertible } \\
\text { Bonds }\end{array}$ \\
\hline Iron and Steel & -22.34 & 1.60 & -20.74 & -22.34 & 0.82 & -21.52 & 0.00 & -0.69 & -0.69 & 0.00 & -0.63 & -0.63 & $(0.63)$ & $\begin{array}{l}\text { Debt Repay- } \\
\text { ment }\end{array}$ \\
\hline $\begin{array}{l}\text { Passenger Trans- } \\
\text { portation Sea }\end{array}$ & 15.20 & 2.55 & 17.75 & 99.53 & 2.29 & 101.82 & 2.13 & )$^{(1.44}$ & 0.70 & 2.13 & )$^{(1.23}$ & 0.90 & 101.82 & $\begin{array}{l}\text { Convertible } \\
\text { Bonds }\end{array}$ \\
\hline
\end{tabular}

Source: Own elaboration (2020)

\section{Industries}

As shown in Table 6, Fishing and Farming, Food Processing, Marine Port Services, Banking and Investment Services, Industrial Machinery, and Oil and gas industries would be ideal to use debt to equity swap as their debt restructuring method. Furthermore, the forest and wood products industries would be better using debt to asset swap as their debt restructuring method. Passenger transportation and sea, electric utilities, and textile and leather goods are better than issuing convertible bonds. Last, iron and steel industries would be better to use a debt repayment agreement as their debt restructuring methods. For industries, most of the industries are having better performance while using debt to an equity swap and issuing convertible bonds. 
Despite this, there are some industries such as forest and wood products and Iron and Steel firms that are better performing while using debt to asset swap and also debt repayment agreement as their debt restructuring methods. As shown in both tables (Table 5 and 6), most industries and firms have better performance while using debt to an equity swap and convertible bonds as their restructuring method. Nevertheless, there are $21.05 \%$ of firms are better suited to using debt to asset swap as their debt restructuring method. However, none of the firms listed is having better performance using a debt repayment agreement. Answering the argument from Sepec and Grazl (2020), which mentioned debt restructuring methods capable of giving better positions, is true because most of the firms listed above have better performance while using debt to equity conversion methods such as debt to an equity swap and issuing convertible bonds.

\section{Conclusion}

Most firms and their industry are better at using debt to equity swap as their debt restructuring methods. Furthermore, it is better to use convertible bonds and debt to asset swap. We found that the value of firms remains the same after using repayment agreement methods. Nevertheless, one industry that is the iron and steel industry is better at using repayment agreement methods because their accumulated value is the highest among other methods. Predominantly, most of the firms perform better while using debt to an equity swap and issuing convertible bonds, proven by an increase in their P/BV and their better capital structure by looking at their DER. Furthermore, debt to asset swaps is better to be used on Firms with high DER. In comparison, a debt repayment agreement is not impacted by the firm's capital structure and its value.

\section{Acknowledgment}

We thank all valuable comments from the anonymous reviewer and conference participants at $1 \mathrm{st}$ ICEMAC 2020. Sukabumi, 19-20 December 2020

\section{References}

Allen and Gale. (2000). Financial contagion. J Polit Econ. 108, 1-33

Bragg, S . (2017). Accountants' guidebook: Third edition: A financial and managerial accounting reference. New York: Accounting Tools Brown, P., Lajbcygier, B., \& LI, S. (2008). Going negative: what to do with negative boo equity stocks. The journal of portfolio management, $35(1), 95-102$

Charalambides, M., \& Koussis, N. (2018). A stochastic model with interacting managerial operating options and debt rescheduling. European Journal of Operational Research, 267, 236-249

Choi, Y.K., \& Han. S.H. (2013). Corporate restructuring, financial deregulation, and firm value: Evidence from Japanese "spin-ins. PacificBasin Finance Journal, 22, 1-13

Damodaran, A. (2010), Applied corporate finance. New York: Wiley.

Damodaran, A (2002). Investment valuation: Tools and techniques for determining the value of any assets. New York: Wiley.

Ebid, I.E. (2009). The impact of capital structure choice on firm performance: empirical evidence from Egypt. Journal of Risk Finance, 10(5), 477-487.

Erić, D., \& Stošić, I. (2013) Korporativno restrukturiranje. Institut ekonomskih nauka i Beogradska bankarska akademija. UK: Beograd Fuady, M. (2001). Pengantar hukum bisnis. Bandung: Citra Aditya Bakti

Gilson, S.C., John, K., \& Lang, L. H. P. (1990). Troubled debt restructurings: an empirical study of private reorganization of firms in default. J. Financ. Econ., 27, 315-353.

Hamada, R. (1972). The effect of the firm's Capital structure on the systematic risk of common stocks, The Journal of Finance, 27(2), 435452.

Harmon. (2020). A primer on restructuring your company's finances. Boston: Harvard Business Review

Hilliard, \& Zhang. (2015). Size and price-to-book effects: Evidence from the Chinese stock markets. Pacific-Basin Finance Journal 32, 4055

Högfeldt, P., \& Oborenko, A. (2005). Does market timing or enhanced pecking order determine capital structure?. ECGI Research Paper Horne, J.C.V., \& Wild, M.W.Jr. (2008). Fundamentals of financial management 13th edition. Harlow: Pearson Education Limited 
Hoshi, T., Koibuchi, S., \& Schaede, U. (2018). The decline in bank-led corporate restructuring in Japan: 1981-2010. J. Jpn. Int. Econ., 47, 8190.

Huang, J.C., \& Huang, C.S. (2011). The effects of bank relationships on firm private debt restructuring: evidence from an emerging market. Res. Int. Bus. Financ. 25, 113-125.

Kim, K., \& Wang. (2019). Debt restructuring through equity issues. Journal of Banking and Finance, 106, 341-356)

Koh, D. D., \& Chang. (2015). Financial distress: Lifecycle and corporate restructuring. Journal of Corporate Finance. 33, 19-33

La Rocca, M., La Rocca, T., Gerace, D., \& Smark, C. (2009). Effect of diversification on capital structure. Accounting Finance, 49(4), 799826

Lee, H.C. (2007). Efficient and inefficient debt restructuring: a comparative analysis of voting rules in workouts. Cornell Int. Law J. 40, 661690.

Lohrke, F., Bedeian, A., \& Palmer, T. (2004). The role of top management teams In formulating and implementing turnaround strategies: A review and research agenda. International J. of Management Reviews 5-6, 63-90

Marie, D. (2013). What we do and do not know about convertible bond financing. Journal of Corporate Finance, 24, 3-20

Masulis, R., \& Korwar, A. (1986). Seasoned equity offerings: an empirical investigation. J. Financ. Econ., 15, 91-118.

Mielcarz, P., \& Osiichuk, D. (2017). Financial restructuring and target capital structure: An iterative algorithm for shareholder value maximization. Review of Accounting and Finance, 17, 280-294

Miyakawa, D., \& Ohashi, K. (2016). Multiple lenders, temporary debt restructuring, and firm performance: evidence from contract-level data. In: Asian Finance Association (AsianFA) 2016 Conference, Asian Finance Association (AsianFA) 2016 Conference. Available at SSRN: https://ssrn.com/abstract $1 / 42724456$.

Modigliani, F., \& Miller, M.H. (1963). Corporate income taxes and the cost of capital: a correction. Am. Econ. Rev. 55 (3), 524-536

Moreno-Bromberg, S., \& Vo, Q. (2017). Resolution of financial distress under agency frictions. J. Bank. Finance, 82, 40-58.

Myers, B. (2004). The determinants of corporate dividend policy. Academy of Accounting and Financial Studies Journal 03, 1-6

Nishihara, M., \& Shibata, T. (2016). Asset sale, debt restructuring, and liquidation. Journal of Economic Dynamics \& Control, 67, 73-92

Pawlina, G. (2010). Underinvestment, capital structure and strategic debt restructuring. J. Corp. Financ., 16, 679-702.

Payne, J. (2018). Debt restructuring in the UK. Eur. Co. Financ. Law Rev., 15, 449-471.

Peraturan Otoritas Jasa Keuangan Republik Indonesia Nomor 30 /POJK.04/2019 Tentang Penerbitan Efek Bersifat Utang Dan/Atau Sukuk Yang Dilakukan Tanpa Melalui Penawaran Umum

Peraturan Otoritas Jasa Keuangan Republik Indonesia Nomor 26 /POJK.04/2020 Tentang Penawaran Yang Bukan Merupakan Penawaran Umum

Peraturan Pemerintah Republik Indonesia Nomor 27 Tahun 1998 Tentang Penggabungan, Peleburan, Dan Pengambilalihan Perseroan Terbatas Peraturan Pemerintah Republik Indonesia Nomor 7 Tahun 2001 Tentang Pemberian Keringanan Pajak Penghasilan Kepada Wajib Pajak Yang Melakukan Restrukturisasi Utang Usaha Melalui Lembaga Khusus Yang Dibentuk Pemerintah

Ross, S., Westerfield, R., \& Jaffe J. (2010). Corporate finance 9th Edition. New York: McGraw Hill

Saleh, N.M., \& Ahmed, K. (2005). Earnings management of distressed firms during debt renegotiation. Account. Bus. Res., 35, 69-86.

Sepec, \& Grazl. (2020), Debt-to-equity conversion in bankruptcy reorganization and post-bankruptcy firm survival. International Review of Law and Economics, 61(C), 1-7.

Shafer, G.A. (1976). Mathematical theory of evidence. New Jersey: Princeton University Press

Stein, J. (1992). Convertible Bonds as Backdood Equity Financing. Journal of Financial Economics, 11, 3-21

Sudarsanam, S., Lai, J. (2001). Corporate financial distress and turnaround strategies: an empirical analysis. Br. J. Manag., 12, 183-199.

Undang-Undang Republik Indonesia Nomor 40 Tahun 2007 Tentang Perseroan Terbatas

Undang-Undang Republik Indonesia Nomor 37 Tahun 2004 Tentang Kepailitan dan Penundaan Kewajiban Pembayaran Utang.

Viva, \& El, H. (2020). Financing decisions: The case of convertible bonds. International Review of Financial Analysis, 67 (2020), 101393 